\title{
Metode procjene dentalne dobi kod odraslih osoba
}

\section{Dental age assessment methods in adult dentitions}

\author{
Sara Huskić $1^{*}$, Dražen Cuculić ${ }^{2}$
}

${ }^{1}$ Sveučilište u Rijeci, Fakultet dentalne medicine, Rijeka, Hrvatska

${ }^{2}$ Sveučilište u Rijeci, Medicinski fakultet, Zavod za sudsku medicinu i kriminalistiku, Rijeka, Hrvatska

\footnotetext{
*Dopisni autor:

Sara Huskić

Sveučilište u Rijeci, Fakultet dentalne medicine, Krešimirova 40, 51000 Rijeka, Hrvatska

E-mail: huskicsara@gmail.com
}

Sažetak. Određivanje dobi predstavlja jedan od glavnih izazova forenzične znanosti. Koristi se za identifikaciju nepoznatih tijela u forenzici i arheologiji, kao i za procjenu dobi u pravnim, legalnim i kriminalističkim slučajevima. Za procjenu se mogu koristiti zubna tkiva zbog izrazite rezistencije svoje anorganske strukture. Kod odraslih je procjena puno zahtjevnija jer se bazira na analizi degenerativnih promjena koje nastaju starenjem i mogu biti vrlo individualne. Postojeće metode procjene dentalne dobi u odraslih osoba dijele se na morfološke, radiološke, biokemijske i molekularne. Učinkovitost metoda pokazala se različitom u različitim etničkim i dobnim skupinama te nije svaka primjenjiva na svakoj skupini zuba. Glavni nedostatak mnogih metoda jesu zahtjevni laboratorijski postupci i dug vremenski period potreban da se metoda izvrši. Pronalaženje univerzalne, jedinstvene metode procjene dobi u odraslih jedan je od glavnih ciljeva forenzičnih stomatologa danas.

Ključne riječi: dentin; forenzična dentalna medicina; metode; odrasli; zubni cement

\begin{abstract}
Age estimation presents one of the main challenges in forensic science. It is used in identification of unknown bodies in forensics and archeology, as well as estimating the age in legal and criminal cases. Dental tissues are used in the estimation because of their resistant inorganic structure. Age estimation is much more challenging in adults because it is based on analysing the degenerative changes that occur as a part of the ageing process and that can be very individual. Methods include: morphological, radiological, biochemical and molecular methods. The efficacy of methods was shown to be variable for various ethnic and age groups, and not every method is applicable for every type of tooth. One of the main faults of many methods is the requirement of sophisticated laboratory equipment and knowledge as well as the time consuming procedures needed to accomplish the method. Finding a universal and standardised method for age estimation in adults is one of the main goals of forensic dentistry today.
\end{abstract}

Key words: adult; dental cementum; dentin; forensic dentistry; methods 


\section{UVOD}

Procjena starosti od izrazito je velike važnosti kod utvrđivanja identiteta nepoznatih osoba i tijela i predstavlja jedan od najvećih izazova forenzičnih stomatologa. Identifikacija tijela provodi se kod arheoloških nalazišta, kao i kod ostalih nalazišta nepoznatih tijela, kostura, žrtava masovnih prirodnih katastrofa te kod slučajeva nestalih oso$b^{1}$. Utvrđivanje dobi živih osoba danas je sve češće potrebno i važno je kod osoba bez valjanih identifikacijskih dokumentata, azilanata², kod djece koja se posvajaju iz inozemstva, starijih osoba koje tvrde da im nije upisan točan datum rođenja te kod povezanosti sa zločinima ${ }^{3-5}$. Ujedno je i važan faktor kod medicinskih postupaka kao što su dijagnostika, terapija i prognoza ${ }^{6}$.

Forenzični znanstvenici i antropolozi nastoje procijeniti biološku dob pojedinca preko koje određuju njegovu kronološku dob, uzimajući u obzir standarde područja u kojem je pronađen?

Za određivanje dobi mogu se koristiti koštana i zubna tkiva koja su rezistentna zbog visokog udjela anorganskih komponenti. Zubno je tkivo najtvrđe tkivo u tijelu i manje je pod utjecajem okolišnih čimbenika (mehaničkih, termičkih, kemijskih i dr.) u odnosu na koštano, te nakon smrti ostaje dugo dobro očuvano ${ }^{8}$.

Kod zubi u razvoju za određivanje kronološke dobi postoje metode koje se baziraju na stadijima razvoja zuba. Međutim, kod odraslih ljudi kod kojih je završen razvoj zuba određivanje starosti bazira se na degenerativnim promjenama koje su često vrlo individualne. Stoga je određivanje starosti kod odraslih manje precizno i mnogo zahtjevnije nego kod mladih ${ }^{4}$.

Cilj je članka napraviti pregled dostupnih metoda za određivanje dentalne starosti kod odraslih osoba čiji je razvoj zuba završio te pokušati utvrditi koja je od metoda najprikladnija za upotrebu.

\section{DEGENERATIVNE PROMJENE NA ZUBIMA}

Procjena starosti kod odraslih osoba (od 25. godine) vrlo je zahtjevan proces jer se postojeće metode oslanjaju na degenerativne promjene na zubima na koje utječe mnogo faktora i koje su jako individualne. Njima pripadaju: apozicija cementa, odlaganje sekundarnog dentina, atricija, resorpcija korijena i gingivna recesija i translucencija korijena ${ }^{9}$.

Cement je vrsta vezivnog tkiva koje okružuje zub u području korijena i oblaže ga u slojevima, što se na mikroskopskim preparatima očituje u vidu koncentričnih linija. Te linije se, poput godova na drvetu, odlažu u pravilnim intervalima i predstavljaju biološki zapis koji može služiti u određivanju dobi pojedinca ${ }^{9}$. Smatra se da se debljina cementa utrostruči između dvadesete i šezdesete godine. Prve su se metode bazirale na mjerenju

Utvrđivanje dobi kod živih osoba danas je sve češće važno kod osoba bez valjanih identifikacijskih dokumentata, azilanata, djece koja se posvajaju iz inozemstva, starijih osoba koje tvrde da im nije upisan točan datum rođenja te kod povezanosti sa zločinom.

debljine cementa, dok novije metode predlažu brojenje linija. Prosječna dob pojedinca računa se tako da se na broj linija nadodaje dob erupcije promatranog zuba. Prema nekim studijama, brojenje inkrementnih ističe se kao precizna metoda u određivanju dobi ${ }^{10}$.

Nakon završetka razvoja primarnog dentina, odnosno nakon završetka formacije krune, u zubu se počinje stvarati sekundarni dentin koji se za života kontinuirano stvara. Posljedično se smanjuje pulpna komora i sužavaju se korijenski kanali jednokorijenskih i višekorijenskih zuba ${ }^{11}$. Ovaj je proces uglavnom pravilan, osim u slučajevima iritacija, bilo fizikalnih, kemijskih ili zubnog karijesa. U metodama koje se oslanjaju na ovaj parametar mjeri se omjer veličine zuba i pulpne komore $^{12}$.

Atricija podrazumijeva trošenje okluzalne površine zuba zbog aktivnosti usljed mastikacije ili parafunkcija. $U$ analizama se mjere vrijednosti trošenja na kvržicama zuba ${ }^{10}$. Pokazalo se da se svi zubi ne troše $u$ istoj mjeri $i$ da razina atricije jako varira među populacijama, što se najviše pripisuje stilu života i genetskim faktorima. Atricija je pod utjecajem okoliša, prehrane i bruksizma ${ }^{13}$. Resorpcija korijena je degenerativna promjena trajnih zuba. Započinje na apikalnoj strani korijena i napreduje prema cervikalnoj ${ }^{14}$. Može varirati od nepostojeće resorpcije, točkaste resorpcije, 


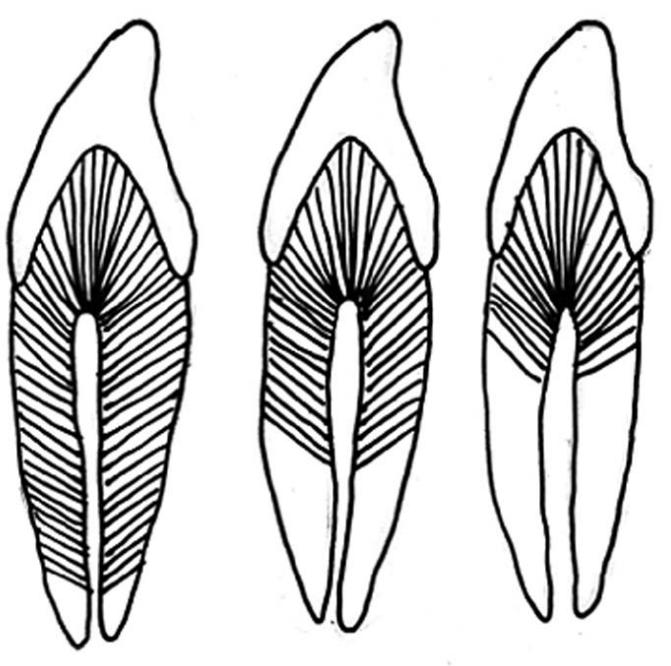

Slika 1. Razine transparencije korjenova Gustafsonova metoda (1950.) $-\mathrm{T} 1$ = primjetna transparencija korijena, $\mathrm{T} 2$ = transparencija korijena preko apikalne trećine, $\mathrm{T} 3$ = transparencija korijena preko apikalne dvije trećine korijena ${ }^{22}$

resorpcije limitirane na cement i ekstenzivne resorpcije cementa i dentina ${ }^{15}$. Istraživanja pokazuju da je mjerenje resorpcije korijena pouzdan parametar u procjeni dobi ${ }^{16}$.

Parodontalna recesija nastaje povlačenjem parodontalnih vlakana koja okružuju zub i napreduje prema korijenu. Na zubima se vidi kao smeđe-žuto područje ispod caklinsko-cementnog spojišta i ono je tamnije od cakline, ali svjetlije od ostatka korijena. Recesije su izražene kod pacijenata koji boluju od parodontnih bolesti, pa je i njegova pouzdanost upitna ${ }^{17}$.

Translucencija korijena je prirodna pojava koja nastaje sklerozacijom peritubularnog dentina $\mathrm{i}$ počinje nakon 25. godine. Napreduje od apeksa korijena prema vratu zuba i raste s dobi (Slika 1). Ova je pojava vidljiva kada se ekstrahirani zub prisloni na izvor svjetlosti. Neki autori smatraju da mjerenje translucencije korijena nije pouzdan čimbenik kod arheloških ostataka jer bi sastavnice tla mogle interferirati s količinom apikalne translucencije ${ }^{18}$, dok drugi autori negiraju postojanje takve interferencije. Visoke temperature $\mathrm{i}$ okluzalne sile mogu utjecati na količinu translucencije $^{19-21}$.

\section{MORFOLOŠKE METODE}

U morfološke metode ubrajaju se metode koje se koriste morfološkim degenerativnim promjena- ma, na uzorcima zubi koji mogu i ne moraju biti obrađeni. Od uzoraka koji se obrađuju uglavnom se koriste izbrusci, dok se oni koji se ne obrađuju, promatraju golim okom i pogodni su kod arheoloških uzoraka kod kojih je jako bitno sačuvati uzorak $^{22}$.

Pionirska metoda iz ove skupine je Gustafsonova metoda iz 1950. godine. Gustafson je promjene na zubnim tkivima promatrao mikroskopski i podijelio ih je u šest kategorija: atricija incizalne i okluzalne površine zuba usljed mastikacije, parodontna recesija, odlaganje sekundarnog dentina, odlaganje cementa, resorpcija korijena i translucencija korijena. Sugerirao je da se ove promjene događaju istovremeno, što se kasnije pokazalo netočnim ${ }^{9,14,23}$.

Premda je ova metoda naširoko korištena u forenzičnim slučajevima, doživjela je i brojne kritike i modifikacije. Glavne su manjkavosti: kompleksnost izvođenja longitudinalnih rezova, nemogućnost primjene na živim osobama, vremenski period izvođenja metode, nemogućnost promatranja određenih parametara (npr. parodontitis zbog nestanka mekih tkiva) te nejednaka važnost parametara $^{9,22}$.

Lamendin je modificirao Gustafsonovu metodu tako da je izbjegao preparaciju zuba i uzeo u obzir samo translucenciju korijena, duljinu korijena zuba i razinu gubitka pričvrstka ${ }^{24,25}$.

Solheimova modifikacija je na Gustafsonovih šest parametara dodavala još boju zuba i hrapavost površine. Parametrima koji zahtijevaju procjenu boje dentina treba se pristupati pažljivo kod neživih osoba jer zubna tkiva nakon smrti postaju tamnija zbog reakcija na okolišne čimbenike nakon smrti ${ }^{26}$.

Morfološke metode pogodne su za korištenje kod identifikacije tijela i u arheološke svrhe kada se koriste neobrađeni uzorci koje želimo sačuvati²2.

\section{RADIOLOŠKE METODE}

Radiografske su snimke neinvazivne, jednostavne metode prikupljanja informacija o stanju u usnoj šupljini i koriste se svakodnevno u većini stomatoloških praksi. Radiološke metode koriste se za procjenu dobi živih i mrtvih osoba. Trenutno su to jedine metode koje se koriste kod živih osoba jer su neinvazivne, a mogu se koristiti i dentalne 
arhive pacijenata koje sadrže RTG snimke. Baziraju se na evaluaciji veličine pulpne komore na panoramskim i periapikalnim snimkama ${ }^{27}$. Mjera veličine pulpne komore zapravo predstavlja debljinu sekundarnog dentina ${ }^{6}$.

Kvaal je prva sugerirala korištenje RTG snimki u procjeni starosti. Parametar na kojeg se bazirala je smanjenje pulpne komore usljed odlaganja sekundarnog dentina. Kako bi se izbjegle deformacije dimenzija, odnosno greške pri mjerenju na snimkama usljed angulacije i uvećanja snimke napravljena su mjerenja omjera više veličina (Slika $2)^{28}$. Bez obzira na to, dvodimenzionalne snimke su i dalje ograničene preciznosti zbog distorzija, superpozicija i loše rezolucije ${ }^{6,29,30}$.

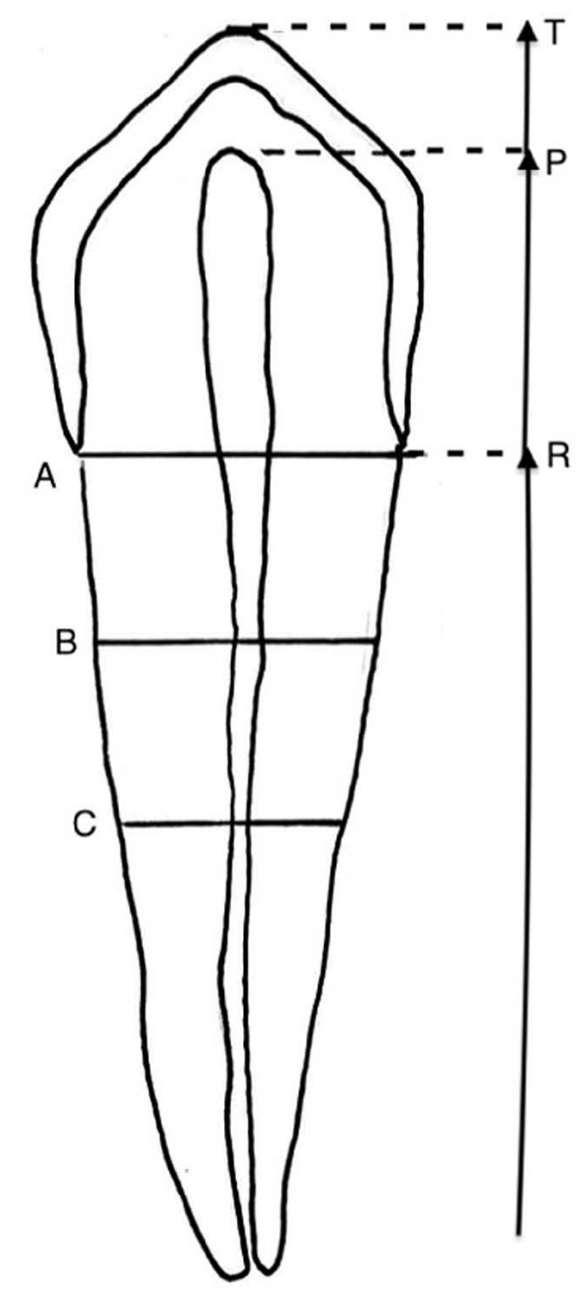

Slika 2. Mjerenja zuba na RTG snimkama Kvaal-metoda ${ }^{28}-\mathrm{T}=$ maksimalna dužina zuba; $\mathrm{R}=$ dužina korijena na mezijalnoj površini; $P=$ maksimalna dužina pulpe; $A$ = širina korijena i pulpe na caklinsko-cementnom (CC) spojištu; B = širina korijena i pulpe između A i C; C = širina korijena i pulpe između apeksa i CC spojišta
Pored periapikalnih i panoramskih snimki, u zadnje se vrijeme koriste i trodimenzionalne snimke, primarno $\mathrm{CBCT}^{29,30}$. СBCT je jednostavna, brza, jeftina, visoko reproducibilna i iziskuje niske doze zračenja ${ }^{31}$. Budući da se sekundarni dentin ne odlaže ravnomjerno na svim stijenkama pulpne komore, trodimenzionalne snimke su puno preciznije od dvodimenzionalnih ${ }^{28,29,32}$.

Na nalazištima i kod pacijenata nisu uvijek prisutni svi zubi u čeljusti, odnosno prisutni su zubi iz različitih skupina. Zato je bitno imati dovoljno do-

Izbor metode ovisit će o dostupnim materijalima za analizu i njihovom stanju te o prosječnoj dobnoj skupini kojoj bi ostatci mogli pripadati. Kod živih osoba uvijek je potrebno uzeti u obzir legalne i etičke razloge, odnosno procijeniti potrebu vađenja zuba i izlaganja pacijenta RTG zračenju u svrhu procjene dentalne dobi.

bru radiološku metodu koja će omogućiti zadovoljavajući prikaz zuba iz svake pojedine skupine ${ }^{33}$.

\section{RACEMIZACIJA ASPARAGINSKE KISELINE}

Morfološke metode korištene u procjeni dentalne dobi često su neprecizne jer su subjektivne, odnosno ovise o iskustvu forenzičnog stomatologa. Biokemijske su metode, s druge strane, objektivne jer se rezultati dobivaju na osnovi specifičnih kemijskih postupaka s kvantificiranim rezultatom ${ }^{34,35}$. Starenjem tkivni proteini prolaze kroz niz neenzimatskih, spontanih reakcija. Primjer takve reakcije je racemizacija proteina. Za vrijeme sinteze proteina sisavci pretežito koriste L-forme aminokiselina. Starenjem ove aminokiseline prelaze iz L-forme u D-formu u procesu koji se zove racemizacija. Dakle, što je osoba starija, u tkivima će imati veći udio D-forme aminokiselina. Smrću se ovaj proces zaustavlja35,36.

Asparaginska kiselina je aminokiselina koja ima najveći stupanj racemizacije i zbog toga se koristi u ovim mjerenjima ${ }^{37}$. Također, racemizacija asparaginske kiseline pokazala je najveću povezanost s kronološkom dobi u odnosu na druge aminokiseline $^{35}$. U tijelu se nalazi u kostima, elastinu, intervertebralnim diskovima te $u$ dentinu i cementu. lako se u cementu racemizacija odvija najbrže, dentin, koji je smješten najviše u unu- 
Tablica 1. Nove metode procjene dobi i njihova učinkovitost ${ }^{41}$

\begin{tabular}{|l|l|c|}
\hline \multicolumn{1}{|c|}{ Vrsta metode } & \multicolumn{1}{c|}{ Tehnika } & Standardna pogreška \\
\hline \multirow{3}{*}{ Kemijske metode } & Racemizacija asparaginske kiseline & + +-3 godine \\
\cline { 2 - 3 } & Odlaganje olova & + /-4,8 godina \\
\cline { 2 - 3 } & Kolagen cross-links & + +-14,9 godina \\
\cline { 2 - 3 } & AGEs & + +-13,7 godina \\
\hline \multirow{2}{*}{ Molekularne metode } & Skraćenje telomera & + +-9,8 godina \\
\cline { 2 - 3 } & Mitohondrijske mutacije & varijabilno \\
\hline & Epigenetske modifikacije & + /-3,75 godina \\
\hline
\end{tabular}

trašnjosti i koji je zaštićen od okolišnih faktora, pokazuje najveću korelaciju s kronološkom dobi. Dakle, računanje omjera D-forme i L-forme asparaginske kiseline u nekom od tkiva može koristiti u određivanju dobi ${ }^{36,38}$.

Dosadašnje studije ovu metodu ističu kao najprecizniju od svih opisanih, međutim činjenica da zahtijeva uništenje zuba, čini je jako invazivnom i nepogodnom za žive osobe ${ }^{22}$.

Odabir zuba za analizu pokazao se značajnim. Za preciznije rezultate potrebno je izolirati kompletan dentin pripadajućeg zuba, a budući da je to lakše izvedivo kod jednokorijenskih zuba, najprikladnijima su se pokazali donji incizivi, očnjaci i prvi premolari34, ${ }^{38}$. Karijes bi, također, mogao utjecati na preciznost rezultata ${ }^{39,40}$. Dosadašnja istraživanja uglavnom ne pokazuju ovisnost učinkovitosti ove metode o rasi ili etničkoj pripadnosti.

\section{OSTALE METODE}

Ostale manje korištene metode uključuju: analize radioaktivnog ugljika, taloženje olova, analizu konačnih produkata glikacije (AGEs), analize skraćenja telomera, analize mutacija mitohondrijskog DNA i analize epigenetskih modifikacija ${ }^{41}$.

Mjerenje koncentracije radioaktivnog ugljika 14C u caklini povezano je s njegovom koncentracijom u atmosferi. Koncentracija radioaktivnog ugljika znatno se povećala 50-ih i 60-ih godina kada su se radila testiranja nuklearnog oružja. Uzimajući u obzir njegovo vrijeme poluraspada, koncentracija ${ }^{14} \mathrm{C}$ u caklini može odrediti kad je zub formiran, odnosno dobiva se podatak o godini rođenja osobe $^{9,38}$.

Olovo je jedan od glavnih sastojaka kojim je kontaminirana hrana i odlaže se u tkivima. Studija na kuvajtskoj populaciji42 dokazala je povezanost dobi s količinom olova u dentinu.

Krajevi kromosoma, odnosno telomere skraćuju se pri svakoj mitozi što ograničava proliferaciju stanica i inducira starenje, diferencijaciju ili apoptozu. Stoga se mjerenje skraćenja telomera istražuje kao potencijalni parametar za određivanje dobi, iako se dosad pokazao relativno nepouzdanim $^{41}$.

Mitohondrijska teorija starenja sugerira podložnost mtDNA mutacijama zbog svog položaja u stanici. Budući da je mitohondrij stanična organela u kojoj se odvija metabolizam stvaranja energije, na stalnoj je meti slobodnih radikala koji oštećuju njezin DNA. Posljedično se stvaraju i akumuliraju nepopravljive lezije na mtDNA. Analiza oštećenja mtDNA izoliranog iz zubnih tkiva mogla bi se koristiti u procjeni dobi ${ }^{43,44}$.

Istražuje se i mogućnost iskorištavanja epigenetike u svrhu određivanja dobi. Dokazana je povezanost razina metilacije i kronološke dobi $u$ uzorcima krvi i dentina ${ }^{41}$.

Izvođenje biokemijskih i molekularnih metoda u procjeni dobi iziskuje posebne laboratorijske uvjete i znanje pa se izvode mnogo rjeđe od morfoloških ili radioloških metoda. Ove su metode relativno nove, ali obećavajuće (Tablica 1 ), pa se iz tog razloga provode mnoge studije koje će testirati njihovu valjanost ${ }^{41}$.

\section{IZBOR METODA}

Svaka od metoda ima svoje prednosti i nedostatke. Izbor metode ovisit će o dostupnim materijalima za analizu, njihovom stanju i prosječnoj dobnoj skupini kojoj bi ostatci mogli pripadati. Većina ih nije primjenjiva na živim osobama, iziskuje preparaciju zubnog tkiva i time uništenje 
uzorka, što se može kositi s kulturološkim, religijskim i etičkim načelima ${ }^{9,45}$.

Analize metoda pokazale su da efikasnost metode varira među pojedinim etničkim skupinama, pa bi zbog toga i svaka od metoda trebala biti testirana na pojedinim etničkim skupinama kako bi se utvrdila njihova učinkovitost ${ }^{45}$. Ukoliko ne postoji dopuštenje za preparaciju zuba kod mrtvih osoba, koriste se isključivo vizualne i radiološke metode. Kod ispitivanja živih osoba, uvijek je potrebno uzeti u obzir legalne i etičke razloge, odnosno procijeniti potrebu vađenja zuba i izlaganja pacijenta RTG zračenju ${ }^{46,47}$.

Također, procjena starosti radi se i prilikom kliničkog intraoralnog i ekstraoralnog pregleda uz dodatne testove ${ }^{46,47}$. Ukoliko je moguće, poželjno je koristiti više metoda, kako dentalnih tako i drugih metoda procjene biološke dobi ${ }^{46,48}$.

\section{ZAKLJUČAK}

Određivanje kronološke dobi preko dentalne dobi predstavlja jedan od glavnih izazova forenzične znanosti. Zubna su tkiva korisna u određivanju dobi jer im anorganske komponenate daju rezistenciju. Opisane su mnoge različite tehnike i studije koje ih evaluiraju i svaka je od navedenih metoda u različitoj mjeri jednostavna, precizna ili pouzdana. Izbor adekvatne metode ovisit će o vrsti uzorka, dobnoj skupini, stanju očuvanosti uzorka te etičkim, religijskim i kulturološkim načelima. Vjerojatnost točne procjene kronološke dobi povećava se korištenjem više različitih metoda. Znanost se usmjerava ka pronalaženju jedinstvene i učinkovite metode procjene dentalne dobi.

Izjava o sukobu interesa: Autori izjavljuju kako ne postoji sukob interesa.

\section{LITERATURA}

1. Jayaraman J, Wong HM, Roberts GJ, King NM, Hugo FV, Cardoso PV et al. Age estimation in three distinct east Asian population groups using southern Han Chinese dental reference dataset. BMC Oral Health 2019;19: 242.

2. Machado CEP, Flores MRP, Lima LNC, Tinoco RLR, Franco A, Bezerra ACB et al. A new approach for the analysis of facial growth and age estimation: Iris ratio. PLoS One 2017;12:1-19.

3. Franklin D, Flavel A, Noble J, Swift L, Karkhanis S. Forensic age estimation in living individuals: methodological considerations in the context of medico-legal practice. Res Rep Forensic Med Sci 2015;5:53-66

4. Rezende Machado AL, Borges BS, Cameriere R, Palhares Machado CE, Alves da Silva RE. Evaluation of Cameriere and Willems age estimation methods in panoramic radiographs of Brazilian children. J Forensic Odontostomatol 2020;30:8-15.

5. Tantanapornkul WB, Kaomongkolgit R, Tohnak S, Deepho $C$, Chansamat R. Dental age assessment based on the radiographic visibility of the periodontal ligament in lower third molars in a Thai sample. J Forensic Odontostomatol 2021;39:32-37.

6. Uğur Aydın Z, Bayrak S. Relationship Between Pulp Tooth Area Ratio and Chronological Age Using Conebeam Computed Tomography Images. J Forensic Sci 2019;64:1096-1099.

7. Šebečić V, Hoch A, Sabalić M. How to estimate dental age in paleodontology?. Bull Int Assoc Paleodont 2010;4:27-32.

8. Gupta P, Kaur H, Shankari GSM, Jawanda MK, Sahi N. Human age estimation from tooth cementum and dentin. J Clin Diagn Res 2014;8:07-10.

9. Brkić $H$, Lessig $R$, da Silva RHA, Pinchi V, Thevissen P. Textbook of Forensic Odonto-Stomatology by IOFOS. $1^{\text {st }}$ Edition. Zagreb: Naklada Slap, 2021;434.

10. Solheim T. Amount of Secondary Dentin as an Indicator of Age. EJDENT 1992;10:193-199.

11. Utama V, Soedarsono N, Yuniastuti M. Assessment of agreement between cervical vertebrae skeletal and dental age estimation with chronological age in an Indonesian population. J Forensic Odontostomatol 2020;38:16-24.

12. Ajmal M, Mody B, Kumar G. Age Estimation Using Three Established Methods. Forensic Sci Int 2001;122:150-4.

13. Bell J. A critique of age estimation using attrition as the sole indicator. J Forensic Odontostomatol 2002;20:38-42.

14. Gustafson G. Age estimation on teeth. J Am Dent Assoc 1950;41:45-54.

15. Singh N, Grover N, Puri N, Singh S, Arora S. Age estimation from physiological changes of teeth: A reliable age marker?. J Forensic Dent Sci 2014;6:113-121.

16. Patel SB, Shah VS, Manjunatha BS. Root Resorption of Teeth as an Age Estimation Marker - In vitro study. Endod Dent Traumatol 1998;14:144-9.

17. Zorba E, Goutas N, Spiliopoulou C, Moratitis K. An Evaluation of Dental Methods by Lamendin and Prince and Ubelaker for Estimation of Adult Age in a Sample of Modern Greeks. Homo 2018;69:1-2.

18. Drusini A, Calliari I, Volpe A. Root Dentine Transparency: Age Determination of Human Teeth Using Computerized Densitometric Analysis. Am J Phys Anthropol 1991;85:25-30.

19. Gibelli D. Thermal modifications of root transparency and implications for aging: a pilot study. J Forensic Sci 2014;59:219-23.

20. Prince DA, Konigsberg LW. New formulae for estimating age-at-death in the Balkans utilizing Lamendin's dental technique and Bayesian analysis. J Forensic Sci 2008;53: 578-87.

21. Ramli UIS, Muhd US, Mohd Yusof MYP. Accuracy of Kvaal's radiographic and translucent dentinal root techniques of extracted teeth in Malay adults for dental age estimation. J Forensic Odontostomatol 2021;30:38-44. 
22. Stavrianos $\mathrm{CH}$, Mastagas D, Stavrianou I, Karaiskou O. Dental Age Estimation of Adults: A Review of Methods and Principals. RJMS 2008;2:258-268.

23. Chandler S, Philips VM. Testing Gustafson's dental age estimation method on a sample of Western Cape adults. SADJ 2018;73:554-558.

24. Baccino E. Determination of Adult Age at Death in the Forensic Context. Forensic Anthropology and Medicine: Complementary Sciences From Recovery to Cause of Death. $1^{\text {st }}$ Edition. New Jersey: Humana Press, 2006; 259-279.

25. Lamendin $H$, Baccino E, Humbert JF, Tavernier JC, Nossintchouk RM, Zerilli A. A simple technique for age estimation in adult corpses: the two criteria dental method. J Forensic Sci 1992;37:1373-1379.

26. Solheim T. A new method for dental age estimation in adults. Forensic Sci Int 1993;59:137-47.

27. Jayaraman J, Roberts GJ, Wong HM, King NM. Dental age estimation in southern Chinese population using panoramic radiographs: validation of three population specific reference datasets. BMC Med Imaging 2018;181:5.

28. Kvaal SI, Kolltveit KM, Thomsen IO, Solheim T. Age estimation of adults from dental radiographs. Forensic Sci Int 1995;74:175-185.

29. Asif MK, Nambiar P, Mani SA, Ibrahim NB, Khan IM, Lokman NB. Dental age estimation in Malaysian adults based on volumetric analysis of pulp/tooth ratio using CBCT data. Leg Med (Tokyo) 2019;36:50-58.

30. Asif MK, Nambiar P, Mani SA, Ibrahim NB, Khan IM, Sukumaran $P$. Dental age estimation employing CBCT scans enhanced with Mimics software: Comparison of two different approaches using pulp/tooth volumetric analysis. J Forensic Leg Med 2018;54:53-61.

31. Helmy MA, Osama M, Elhindawy MM, Mowafey B. Volume analysis of second molar pulp chamber using cone beam computed tomography for age estimation in Egyptian adults. J Forensic Odontostomatol 2020;30:25-34.

32. Haghanifar S, Ghobadi F, Vahdani N, Bijani A. Age estimation by pulp/tooth area ratio in anterior teeth using cone-beam computed tomography: comparison of four teeth. J Appl Oral Sci 2019;27:1-8.

33. Molina A, Bravo M, Fonseca GM, Márquez-Grant $N$, Martín-de-Las-Heras S. Dental age estimation based on pulp chamber/crown volume ratio measured on CBCT images in a Spanish population. Int J Legal Med 2021; 135:359-364.

34. Wochna K, Bonikowski R, Śmigielski J, Berent J. Aspartic acid racemization of root dentin used for dental age estimation in a Polish population sample. Forensic Sci Med Pathol 2018;14:285-294.

35. Tiplamaz S, Gören MZ, Yurtsever NT. Estimation of Chronological Age from Postmortem Tissues Based on
Amino Acid Racemization. J Forensic Sci 2018;63:15331538.

36. Chen S, Lv Y, Wang D, Yu X. Aspartic acid racemization in dentin of the third molar for age estimation of the Chaoshan population in South China. Forensic Sci Int 2016;266:234-238.

37. Verma M, Verma N, Sharma R, Sharma A. Dental age estimation methods in adult dentitions: An overview. J Forensic Dent Sci 2019;11:57-63.

38. Alkass K, Buchholz BA, Ohtani S, Yamamoto T, Druid H, Spalding KL. Age estimation in forensic sciences: application of combined aspartic acid racemization and radiocarbon analysis. Mol Cell Proteomics 2010;9:1022-1030.

39. Sirin N, Matzenauer C, Reckert A, Ritz-Timme S. Age estimation based on aspartic acid racemization in dentine: what about caries-affected teeth?. Int J Legal Med 2018;132:623-628.

40. Kumar PA, Kanchan T. Age estimation based on aspartic acid racemization in caries-affected teeth: need for further explorations. Int J Legal Med 2018;132:623-628.

41. Adserias-Garriga J, Zapico SC. Age Assessment in Forensic Cases: Anthropological, Odontological and Biochemical Methods for Age Estimation in the Dead. Mathews J Foren 2018;1:1-6.

42. Al-Qattan SI, Elfawal MA. Significance of teeth lead accumulation in age estimation. J Forensic Leg Med 2010;17:325-328.

43. Zapico SC, Ubelaker DH. Relationship Between Mitochondrial DNA Mutations and Aging. Estimation of Ageat-death. J Gerontol A Biol Sci Med Sci 2016;71:445-50.

44. Li H, Slone J, Fei L, Huang T. Mitochondrial DNA Variants and Common Diseases: A Mathematical Model for the Diversity of Age-Related mtDNA Mutations. Cells 2019;18:608.

45. Prasad H, Kala N. Accuracy of two dental age estimation methods in the Indian population - A meta-analysis of published studies. J Forensic Odontostomatol 2019;3:211.

46. Solheim T, Vonen A, Kval SI. Odontological Age Estimation of Living Persons with Special Reference to Young Asylum Seekers: The Norwegian Approach. Acta Stomatol Croat 2008;42:350-359.

47. American Board of Forensic Odontology [Internet]. Colorado: ABFO Standards and Guidelines for Dental Age Assessment, Inc. c2021 [cited 2021 Mar 1]. Available from: http://abfo.org/wp-content/uploads/2021/02/ ADA-Technical-Report-No.-1077_July_2020.-02-2021. pdf.

48. Cattaneo C, De Angelis D, Ruspa M, Gibelli D, Cameriere $\mathrm{R}$, Grandi M. How old am I? Age estimation in living adults: a case report. J Forensic Odontostomatol 2008; 26:39-43. 